\title{
Ion Flotation of Copper(II) and Lead(II) from Environmental Water Samples
}

\author{
${ }^{1}$ GHAZY, S. E.; ${ }^{1}$ EL-MORSY, S. M.; ${ }^{2}$ RAGAB, A. H. \\ ${ }^{I}$ Chemistry Department, Faculty of Science, Mansoura University, P.O. Box ,66 Mansoura, Egypt \\ ${ }^{2}$ New Mansoura Water Treatment Plant, Mansoura City, Egypt.E-mail: ghazyse@mans.edu.eg.shabanghazy@yahoo.com
}

\begin{abstract}
The present study aims to develop a simple, rapid and economic procedure for copper(II) and lead(II) removal under the optimum conditions investigated. It is based on the complex formation between $\mathrm{Cu}^{2+}$ and $\mathrm{Pb}^{2+}$ ions and diphenylcarbazone (HDPC) followed by flotation with oleic acid (HOL) surfactant. The different parameters (namely: solution $\mathrm{pH}$, HDPC, HOL, copper and lead concentrations, ionic strength, temperature and the presence of foreign ions) influencing the flotation process were examined. Nearly, $100 \%$ of $\mathrm{Cu}^{2+}$ and $\mathrm{Pb}^{2+}$ ions were removed from aqueous solutions at $\mathrm{pHs} 6$ and 7 , respectively at room temperature $(\sim 25$ $\left.{ }^{\circ} \mathrm{C}\right)$. The procedure was successfully applied to recover almost copper(II) and lead(II) spiked to some natural water samples. Due to the rapid, simple and economic nature of the procedure, a flotation mechanism is suggested for metal removal in wastewater systems. @ JASEM
\end{abstract}

Environmental pollution, mainly in the aquatic systems, due to developments in industry, is one of the most significant problems of this century. Many industrial wastewater streams (ca. the metal working, semiconductor, and copper industries, mine water, etc.) contain heavy metals, which are of great environmental concern and must be removed prior to water discharge or water recycling. Copper has received considerable attention owing to its uses in metallurgy, chemical industries and is necessary for other many biological important functions (Freematle, 1989; Khalifa et al., 2001). When levels of $\mathrm{Cu}$ exceed certain values, however, defense mechanisms to protect against excess $\mathrm{Cu}$ are overcome and toxicity results. The reported list of toxic $\mathrm{Cu}$ species (Sorenson, 1991) often includes $\mathrm{Cu}(\mathrm{OH})^{+}$, $\mathrm{Cu}_{2}(\mathrm{OH})_{2}{ }^{2+}$ and $\mathrm{CuCO}_{3}$. However, without doubt, $\mathrm{Cu}^{2+}$ ions that are present in various aqueous solutions (their presence is a function of $\mathrm{pH}$ ) are considered to be the most toxic of dissolved copper species (Freematle, 1989; Khalifa et al., 2001; Sorenson, 1991). Excess copper in water is not only harmful to human beings, but also interferes with the self-purification of bulk water (Ghazy et al., 2006) and adverse effect on the microbiological treatment of wastewater (Ghazy et al., 2001).

Lead is a natural compound that exists in elemental, inorganic, and organic forms. It is used in mining, smelting, refining, battery manufacturing, soldering, electrical wiring, home demolition and construction, painting, ceramic glazing, and the making of stained glass. The increasing presence of lead is very problematic to surface water and underground water due to their mobility and great toxicity (Meunier et al., 2003; Yan and Viraraghavan, 2003). The heavy metal lead is among the most common pollutant found in industrial effluents. Even at low concentration, this metal can be toxic to organisms, including humans and can damage the nervous system, kidneys, and reproductive system, particularly in children (Sheng et al., 2004). Also, lead is known to have a toxic effect on the neuronal system and the function of the brain cells (Ho et al., 2001; Freedman et al., 1990; Goldstein, 1990). The U.S. Environmental Protection Agency (EPA) requires lead not to exceed $0.015 \mathrm{mg} .1^{-1}$ in drinking water (ATSDR, 1999). Therefore, from the viewpoint of pollution, environmental chemistry, and geochemistry, it is necessary to establish a rapid, and simple procedure for copper and lead removal. Numerous techniques for the separation, removal and control of metal toxicants have been reported (Blöcher et al., 2003; Ghazy, 1995; Leyden and Wegscheider, 1981). Although, adsorption has been well established as a technology for removing toxic compounds from wastes or wastewaters (Zouboulis et al., 1994), the process may face filter-blocking problems. Also, sedimentation is a relatively slow process when dealing with biological materials that are usually of low density. Flotation as a separation process has recently received a considerable interest owing to its simplicity, rapidity, economy, good separation yields $(\mathrm{R}>95 \%)$ for small impurity agent concentrations $\left(10^{-6}-10^{-2} \mathrm{~mol} \mathrm{l}^{-1}\right)$, a large possibility of application for species having different nature and structure, flexibility and friability of equipment and processing for recovery purpose (Stoica et al., 1998). It is believed that this process will be soon incorporated as a clean technology to treat water and wastewater (Rubio et al., 2002). Therefore, flotation technique was selected for this investigation.

Ion flotation involves the removal of surfaceinactive ions (colligend) from aqueous solutions by adding surfactants which act as collectors. The subsequent passage of gas bubbles through the solution transfers the surface-active ions to the top (. Doyle, 2003; Lazaridis, 2004) Compared to other separation methods, ion flotation has advantages in its ease of operation and low costs. It shows particular promise for treating large volumes of dilute aqueous solutions (Doyle and Lui, 2003).

Although some work have been carried out for ion flotation of copper (Khalifa et al., 2001; Lazaridis, 2004; Doyle and Lui 2003; Ghazy and Kabil, 1994; 
Stalidis et al., 1989; Stoica et al., 2001; Liu and Doyle, 2001a; Girek et al., 2004) and lead (Lui and Doyle, 2001b; Matis and Mavros, 1991) from aqueous, fresh and wastewaters, and that diphenylcarbazone (HDPC) was used as a complexing agent for spectrophotometric determination of metal cations (Balt and Van Dalen, 1963; Steven, 1966; Trinder, 1966), no attention has been paid towards the use of HDPC as complexing agent for the flotation of $\mathrm{Cu}$ (II) and $\mathrm{Pb}$ (II). Therefore, the objective of the present work was to investigate the feasibility of developing the use of HDPC as chelating agent for $\mathrm{Cu}$ (II) and $\mathrm{Pb}$ (II) removal from aqueous media by ion flotation, under the recommended conditions, in the presence of oleic acid as a surfactant.

\section{MATERIALS AND METHODS}

\section{Reagents and solutions}

Unless otherwise stated, all reagents used were of analytical-reagent grades. All aqueous solutions were prepared in double distilled water. Copper sulfate, $\mathrm{CuSO}_{4} \quad .5 \mathrm{H}_{2} \mathrm{O}$ or $\mathrm{CuCl}_{2} \cdot 2 \mathrm{H}_{2} \mathrm{O}, \quad(\mathrm{BDH}$ limited, Poole, England) was used as the source of divalent copper. A stock copper solution of 1000 $\mathrm{mg} \mathrm{l}^{-1}$ concentration was prepared and the working solutions were made by diluting the former with double distilled water. A lead nitrate $\mathrm{Pb}\left(\mathrm{NO}_{3}\right)_{2}$ (Aldrich) stock solution of $780 \mathrm{mg} \mathrm{l}^{-1}$ concentration was prepared. The working solutions were made by diluting with doubly distilled water. Oleic acid (HOL) was used directly as received. Its stock solution, $6.36 \times 10^{-2} \mathrm{~mol} \mathrm{l}^{-1}$, was prepared from the food grade with sp. gr. 0.895 (provided from J.T. Baker Chemical Co.) by dispersing $20 \mathrm{ml} \mathrm{HOL}$ in 1 1 of kerosene. Diphenylcarbazone (HDPC) stock solution (Koch-Light Laboratories LTD, England), $1.0 \times 10^{-2} \mathrm{~mol} \mathrm{l}^{-1}$, was prepared by dissolving the requisite amount in the least amount of ethyl alcohol and completing to $100 \mathrm{ml}$ with doubly distilled water daily before use. The $\mathrm{pH}$ of the solutions during experiments was adjusted with $\mathrm{HCl}, \mathrm{HNO}_{3}, \mathrm{H}_{2} \mathrm{SO}_{4}$ and/or $\mathrm{NaOH}$.

\section{Apparatus}

The flotation and separation cells were of two types (Ghazy and Kabil, 1994). Type (a) was a cylindrical tube of $29 \mathrm{~cm}$ length and $1.2 \mathrm{~cm}$ inner diameter with a stopcock at the bottom and a stopper at the top. This cell was used to study the different factors affecting the separation of the investigated ions from aqueous solutions. Type (b) was a glass cylinder of $6 \mathrm{~cm}$ inner diameter and 45 cm length with a stopcock at the bottom and a quick-fit stopper at the top. This cell was used to study the separation of the investigated ions from 1 1 of some natural water samples. The $\mathrm{pH}$ values of the solutions were measured using ORION (model 720 A) $\mathrm{pH}$ meter. The concentrations of $\mathrm{Cu}(\mathrm{II})$ and $\mathrm{Pb}$ (II) were determined using Pekin-Elmer 2380
Atomic Absorption Spectrophotometer with airacetylene flame at 324.7 and $217.0 \mathrm{~nm}$, respectively. The stirring of the solutions was performed with a magnetic stirrer Model VEHP, Scientifica, Italy.

\section{Recommended procedures}

A suitable aliquot containing known amount of $\mathrm{Cu}$ (II) or $\mathrm{Pb}$ (II) specified for each investigation, was mixed with a suitable amount of DPC followed by addition of $3 \mathrm{ml}$ of double distilled water. After adjusting the $\mathrm{pH}$ to the required value, the solution was transferred to the flotation cell (a) and the total volume was made up to $10 \mathrm{ml}$ with doubly distilled water. The cell was shaken well for few seconds, to ensure complexation. To this, $3 \mathrm{ml}$ of HOL (of known concentration) was added. The cell was then inverted upside down twenty times by hand. Meanwhile, the stopper of the cell was removed to permit air movement. After allowing it to stand for 5 min for complete flotation, the concentration of $\mathrm{Cu}(\mathrm{II})$ or $\mathrm{Pb}(\mathrm{II})$ in the mother liquor was determined. The floatability (F) of $\mathrm{Cu}$ (II) was determined from the relationship:

$$
\mathrm{F}=\left(\mathrm{C}_{\mathrm{i}}-\mathrm{C}_{\mathrm{f}}\right) / \mathrm{C}_{\mathrm{i}} \times 100 \%
$$

where $C_{i}$ and $C_{f}$ denote the initial and final concentrations of $\mathrm{Cu}(\mathrm{II})$ or $\mathrm{Pb}$ (II) in the mother liquor, respectively. All experiments were carried out at room temperature $\left(25 \pm 1^{\circ} \mathrm{C}\right)$.

To asses the applicability of the procedure, another series of experiments was conducted on 11 suspension of clear and pre-filtered natural water samples with an initial $\mathrm{pH}$ adjusted to 7.0. These suspensions were placed in flotation cell (b) containing 6.4 or $12.8 \mathrm{mg}$ of $\mathrm{Cu}^{2+}$ or $\mathrm{Pb}^{2+}$ ions, $4 \times 10^{-4} \mathrm{~mol} \mathrm{l}^{-1} \mathrm{HDPC}, 10 \mathrm{ml}$ of $1 \times 10^{-4} \mathrm{~mol} \mathrm{l}^{-1} \mathrm{HOL}$ and stirred magnetically for $10 \mathrm{~min}$ at $250 \mathrm{rpm}$.

\section{RESULTS AND DISSCUSSION}

\section{Effect of $\mathrm{pH}$ of the Medium}

According to our previous knowledge of flotation processes and the fact that the $\mathrm{pH}$ of the medium is a highly significant factor in this respect, therefore, it was the first variable to be optimized. Initial series of experiments were carried out to investigate the suitable acid (ca. $\mathrm{HNO}_{3}, \mathrm{HCl}$ or $\mathrm{H}_{2} \mathrm{SO}_{4}$ ) for controlling $\mathrm{pH}$ in the flotation of $\mathrm{Cu}^{2+}$ or $\mathrm{Pb}^{2+}$ ions. It was found that maximum floatation efficiency of $\mathrm{Cu}^{2+}$ or $\mathrm{Pb}^{2+}$ ions was attained in the presence of $\mathrm{HNO}_{3}$. Therefore, control of $\mathrm{pH}$ was carried out with $\mathrm{HNO}_{3}$ throughout. Moreover, the floatability did not exceed $40 \%$ in the presence of HOL only. Hence, trials were made to float $\mathrm{Cu}^{2+}$ and $\mathrm{Pb}^{2+}$ ions in the presence of other additives such as HDPC.

Several experiments were carried out to investigate the relation between the floatability of $1 \times 10^{-4} \mathrm{~mol} \mathrm{l}^{-}$ ${ }^{1} \mathrm{Cu}^{2+}$ or $\mathrm{Pb}^{2+}$ ions and $\mathrm{pH}$ (adjusted by $\mathrm{HNO}_{3}$ ) using the systems: i) $2 \times 10^{-3} \mathrm{~mol}^{-1}$ of $\mathrm{HOL}$ without additives; ii) $2 \times 10^{-4} \mathrm{~mol} \mathrm{l}^{-1} \mathrm{HDPC}+1 \times 10^{-3} \mathrm{~mol} \mathrm{l}^{-1}$ 
HOL. The results obtained are plotted in Figure 1 ( $\mathrm{a}$ and $\mathrm{b}$ ).

On using HDPC, the floatability of $\mathrm{Cu}^{2+}$ increases up to $\sim 100 \%$, reaches its maximum value in the pH range 5 - 6 and then decreases (Figure 1a) while

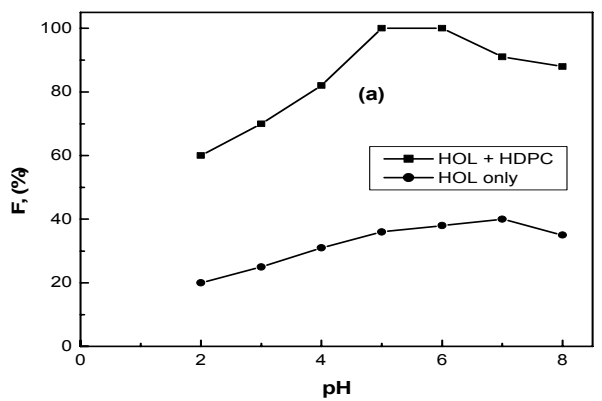

that of $\mathrm{Pb}^{2+}$ reaches its maximum value in the range $6.5-8.0$. Therefore, pHs 6 and 7 were optimized for the flotation experiments of $\mathrm{Cu}^{2+}$ and $\mathrm{Pb}^{2+}$ ions, respectively.

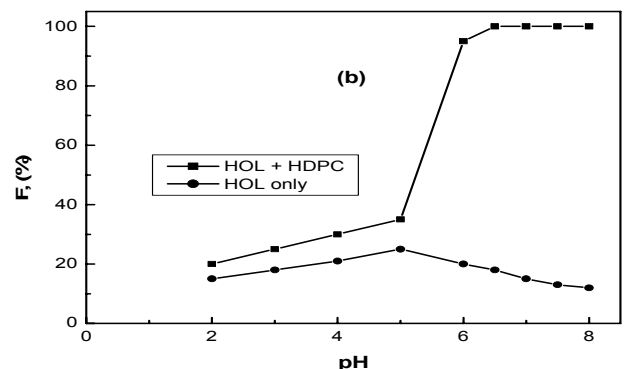

Figure1. Floatability (\%) of $1 \times 10^{-4} \mathrm{~mol}^{-1} \mathrm{Cu}^{2+}$ ions (a) or $\mathrm{Pb}^{2+}$ ions (b) at different $\mathrm{pH}$ values using $2 \times 10^{-4} \mathrm{~mol}^{-1}$ of $\mathrm{HDPC}$ and $1 \times 10^{-}$ ${ }^{3} \mathrm{~mol} \mathrm{l}^{-1}$ of HOL.
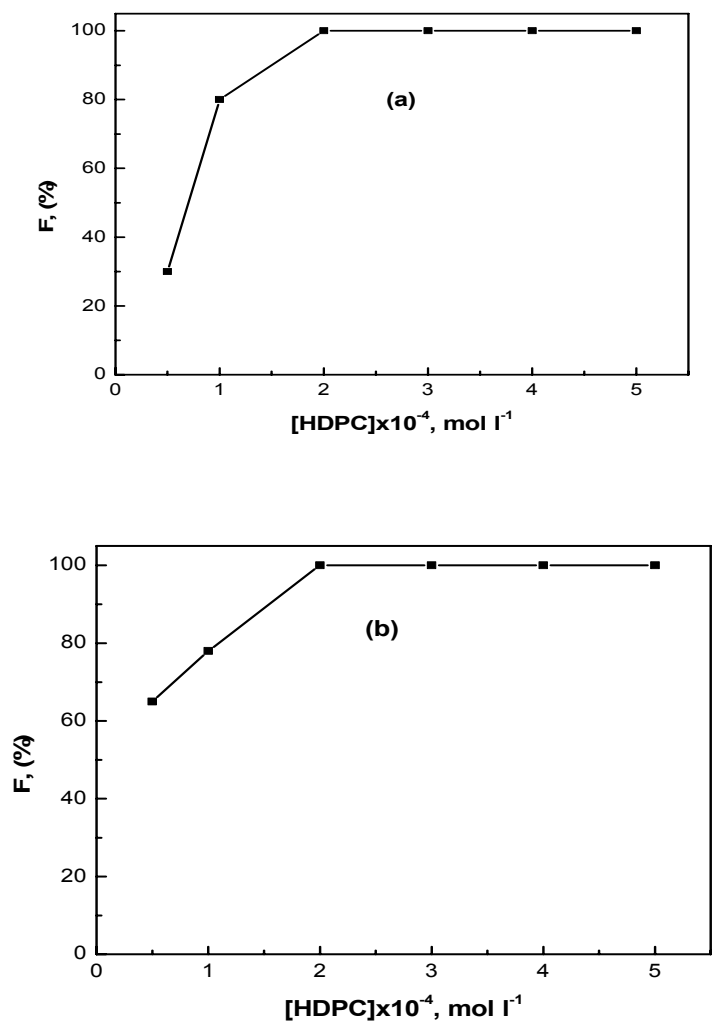

Figure 2. Floatability (\%) of $1 \times 10^{-4} \mathrm{~mol} \mathrm{l}^{-1} \mathrm{Cu}^{2+}$ ions at $\mathrm{pH} 6$ (a) or $\mathrm{Pb}^{2+}$ ions at $\mathrm{pH} 7$ (b) using different concentrations of HDPC and $1 \times 10^{-3} \mathrm{~mol} \mathrm{l}^{-1}$ of HOL. 

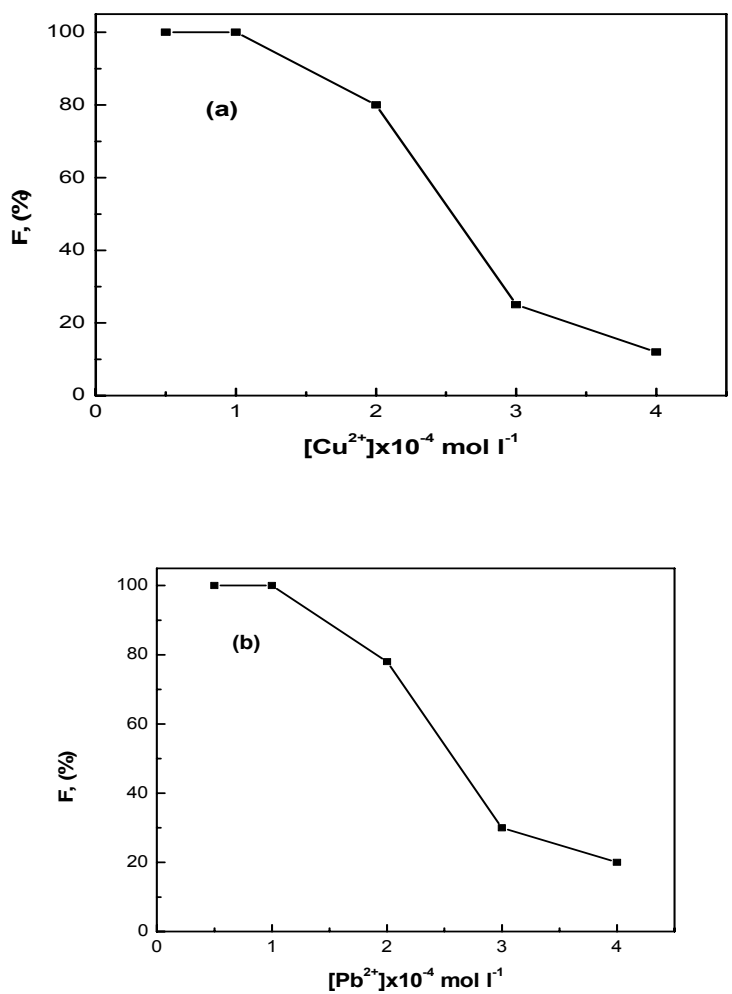

Figure 3. Floatability (\%) of different concentrations of $\mathrm{Cu}^{2+}$ ions at $\mathrm{pH} 6$ (a) or $\mathrm{Pb}^{2+}$ ions at $\mathrm{pH} 7$ (b) using $2 \times 10^{-4} \mathrm{~mol}^{-1}$ of $\mathrm{HDPC}$ and $1 \times 10^{-3} \mathrm{~mol} \mathrm{l}^{-1}$ of HOL.
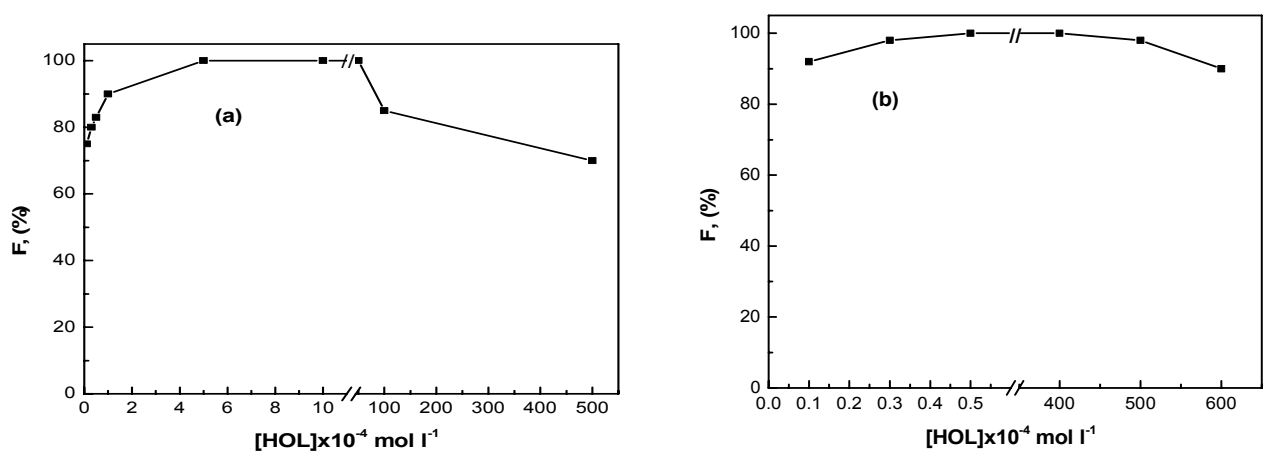

Figure 4. Floatability (\%) of $1 \times 10^{-4} \mathrm{~mol}^{-1} \mathrm{Cu}^{2+}$ ions at $\mathrm{pH} 6$ (a) or $\mathrm{Pb}^{2+}$ ions at $\mathrm{pH} 7$ (b) using different concentrations of $\mathrm{HOL}$ and $2 \times 10^{-3} \mathrm{~mol} \mathrm{l}^{-1}$ of HDPC

\section{Effect of the Ligand and Metal Ion Concentrations}

Two parallel series of experiments were undertaken to study the influence of changing HDPC concentration Figure 2 ( $\mathrm{a}$ and $\mathrm{b}$ ) and changing copper and lead concentrations Figure 3 ( $a$ and $b$ ) on the floatability percentage of $\mathrm{Cu}^{2+}$ or $\mathrm{Pb}^{2+}$ ions from aqueous solutions at $\mathrm{pHs} 6$ and 7 , respectively using $1 \times 10^{-3} \mathrm{~mol}^{-1} \mathrm{HOL}$. As can be seen from the figures, the removal percentage of $\mathrm{Cu}^{2+}$ or $\mathrm{Pb}^{2+}$ ions was directly proportional to HDPC concentration and maximum floatability $(\sim 100 \%)$ was achieved at $1: 2\left(\mathrm{M}^{2+}:\right.$ HDPC $)$ ratio. These results agree well with those obtained in Figure 3 (a and b), where the floatability of metal ions decreased at their higher concentrations owing to the fact that there is no sufficient amount of HDPC for binding them. Also, these data are in accordance with the literature (Balt and Van Dalen, 1963; Steven, 1966; Trinder, 1966), where the divalent metal ions of $\mathrm{Cu}$ and $\mathrm{Pb}$ ions react with HDPC to form 1:2 neutral complexes according to the following equation: $\mathrm{M}^{2+}+2 \mathrm{HDPC}=\mathrm{M}(\mathrm{HPDC})_{2}+2 \mathrm{H}^{+}$(2) 
Moreover, the excess of HDPC has no adverse effect on the flotation process which may find application for the removal of $\mathrm{Cu}^{2+}$ or $\mathrm{Pb}^{2+}$ ions from different samples and matrices. Accordingly, $2 \times 10^{-4} \mathrm{~mol}^{-1}$ of HDPC was used in the recommended procedure.

\section{Effect of the Surfactant Concentration}

Experiments were performed to float $1 \times 10^{-4} \mathrm{~mol} \mathrm{l}^{-1}$ $\mathrm{Cu}^{2+}$ ions at $\mathrm{pH} 6$ (Figure $4 \mathrm{a}$ ) or $\mathrm{Pb}^{2+}$ ions at $\mathrm{pH} 7$ (Figure 4b) using $2 \times 10^{-4} \mathrm{~mol}^{-1}$ of HDPC and different concentrations of HOL. It was observed that the maximum floatability $(\sim 100 \%)$ was attained in the HOL concentration ranges of $5 \times 10^{-4}-5 \times 10^{-3}$ mol $1^{-1}$ for $\mathrm{Cu}^{2+}$ ions and $3 \times 10^{-5}-4 \times 10^{-2}$ mol. $1^{-1}$ for $\mathrm{Pb}^{2+}$ ions, below which the flotation decreases. This may be attributed to the presence of insufficient amounts of surfactant required for complete flotation.

At higher surfactant concentration the poor flotation is caused by the formation on the air bubble surface of a stable, hydrated envelope of surfactant or, perhaps, by forming a miscelle (Ghazy et al., 2004). Therefore, $3 \times 10^{-3} \mathrm{~mol}^{-1} \mathrm{l}^{-1}$ of HOL was fixed throughout all the measurements for the removal of $\mathrm{Cu}$ (II) or $\mathrm{Pb}$ (II) .

\section{Effect of Temperature}

To study the effect of temperature on the flotation efficiency, the $\mathrm{Cu}^{2+}$ or $\mathrm{Pb}^{2+}$ ions and HDPC as a first solution and HOL as a second solution were either heated or cooled to the same temperature in a water bath. Both solutions were quickly poured at a time zero into the flotation cell jacketed with $1 \mathrm{~cm}$ thick fiberglass insulation. The flotation procedure was then followed over the range $10-80^{\circ} \mathrm{C}$. It was found that the floatability of the systems $\mathrm{Cu}^{2+}$ HDPC and $\mathrm{Pb}^{2+}$-HDPC was not markedly affected by raising the temperature in this range; it just made an acceleration of the flotation process. Since most industrial influents are usually hot, the simple procedure presented here may find its application in the removal of $\mathrm{Cu}^{2+}$ or $\mathrm{Pb}^{2+}$ ions directly from industrial wastewaters. Therefore, subsequent, measurements were carried out at room temperature, ca. $25 \pm 1^{\circ} \mathrm{C}$.

\section{Effect of Ionic Strength}

Table 1 shows the effect of ionic strength on the floatability of $1 \times 10^{-4} \mathrm{~mol} \mathrm{l}^{-1} \mathrm{Cu}^{2+}$ ions at $\mathrm{pH} 6$ or $1 \times 10^{-4} \mathrm{~mol} \mathrm{l}^{-1} \mathrm{~Pb}^{2+}$ ions at $\mathrm{pH} 7$ using $2 \times 10^{-4} \mathrm{~mol}^{-1}$ of HDPC and $3 \times 10^{-3} \mathrm{~mol} \mathrm{l}^{-1} \mathrm{HOL}$. The cations and anions which nearly resemble that present in natural waters are taken into consideration. The data are given in Table 1. As can be seen, all the salts added to the floating medium have no effect on flotation efficiency. Only $\mathrm{CaCl}_{2}$ and $\mathrm{MgCl}_{2}$ decrease the flotation efficiency to some extent owing to the formation of calcium and magnesium oleates resulting in a decrease of the concentration of oleic acid surfactant needed for flotation. The adverse effect of $\mathrm{CaCl}_{2}$ and $\mathrm{MgCl}_{2}$ can be overcome by adding slight excess of oleic acid surfactant.

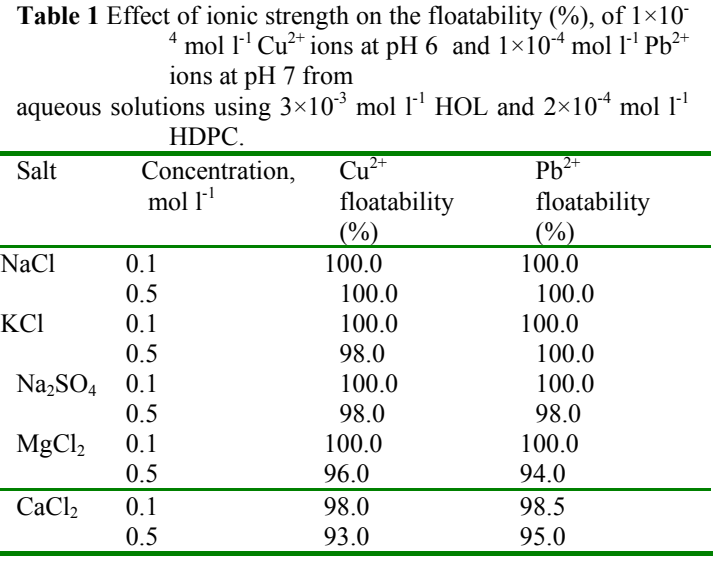

\section{Effect of Some Foreign Ions}

Under the optimized conditions determined, the percentage removal of $1 \times 10^{-4} \mathrm{~mol} \mathrm{l}^{-1} \mathrm{Cu}^{2+}$ at $\mathrm{pH} 6$ and $1 \times 10^{-4} \mathrm{~mol}^{-1} \mathrm{~Pb}^{2+}$ at $\mathrm{pH} 7$ using $2 \times 10^{-4} \mathrm{~mol} \mathrm{l}^{-1}$ of HDPC and $3 \times 10^{-3}$ mol $1^{-1} \mathrm{HOL}$ was studied. High concentrations of various cations and anions usually found in some water samples were investigated. All cations were used as their nitrates whereas the anions were used as their sodium salts. The tolerable amounts of each ion giving a maximum error of $\pm 2 \%$ in the flotation efficiency are summarized in Table (2). It can be seen that most of the investigated ions did not interfere. Only $\mathrm{Pb}^{2+}$ interferes in the flotation of $\mathrm{Cu}(\mathrm{II})$ while $\mathrm{Cd}^{2+}$, $\mathrm{Co}^{2+}, \mathrm{Ni}^{2+}, \mathrm{Ag}^{+}, \mathrm{Cu}^{2+}$ and $\mathrm{Al}^{3+}$ ions interfere in the flotation of $\mathrm{Pb}(\mathrm{II})$ which may be due to a competition between these ions and $\mathrm{Cu}$ (II) and $\mathrm{Pb}$ (II) towards HDPC. This effect could be overcome by increasing the HDPC concentration. Thus, the recommended procedure could be fairly employed for the removal of $\mathrm{Cu}^{2+}$ and $\mathrm{Pb}^{2+}$ ions from various complex water samples. 


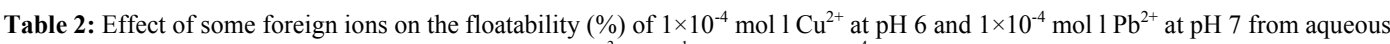
solutions using $3 \times 10^{-3} \mathrm{~mol} \mathrm{l}^{-1} \mathrm{HOL}$ and $2 \times 10^{-4} \mathrm{~mol} 1 \mathrm{HDPC}$.

\begin{tabular}{lllll}
\hline Ion & {$[\mathrm{Ion}] /\left[\mathrm{Cu}^{2+}\right]$} & $\mathrm{F}(\%)$ of $\mathrm{Cu}^{2+}$ & {$[\mathrm{Ion}] /\left[\mathrm{Pb}^{2+}\right]$} & $\mathrm{F}(\%)$ of $\mathrm{Pb}^{2+}$ \\
$\mathrm{K}^{+}$ & 10000.0 & 99.9 & 20000.0 & 99.9 \\
$\mathrm{Na}^{+}$ & 10000.0 & 100.0 & 5000.0 & 100.0 \\
$\mathrm{Ba}^{2+}$ & 5000.0 & 100.0 & 500.0 & 100.0 \\
$\mathrm{Ag}^{+}$ & 50.0 & 99.7 & 2.0 & 99.7 \\
$\mathrm{Sr}^{2+}$ & 100.0 & 100.0 & 200.0 & 100.0 \\
$\mathrm{Mg}^{2+}$ & 5000.0 & 100.0 & 2500.0 & 100.0 \\
$\mathrm{Ni}^{2+}$ & 900.0 & 99.9 & 0.5 & 99.7 \\
$\mathrm{Co}^{2+}$ & 900.0 & 99.8 & 0.5 & 99.9 \\
$\mathrm{Mn}^{2+}$ & 800.0 & 99.7 & 500.0 & 99.9 \\
$\mathrm{Cd}^{2+}$ & 100.0 & 99.8 & 0.1 & 99.9 \\
$\mathrm{Ca}^{2+}$ & 10000.0 & 99.9 & 1000.0 & 99.8 \\
$\mathrm{NH}_{4}{ }^{+}$ & 10000.0 & 99.7 & 635.3 & 99.7 \\
$\mathrm{Hg}^{2+}$ & 100.0 & 99.9 & 50.0 & 99.7 \\
$\mathrm{Zn}^{2+}$ & 70.0 & 100.0 & 20.0 & 100.0 \\
$\mathrm{Cu}^{2+}$ & - & - & 5.0 & 99.9 \\
$\mathrm{Al}^{3+}$ & 50.0 & 99.5 & 5.0 & 99.7 \\
$\mathrm{~Pb}^{2+}$ & 5.0 & 99.2 & - & - \\
$\mathrm{SO}_{4}^{2-}$ & 5000.0 & 99.8 & 5000.0 & 99.8 \\
$\mathrm{NO}_{3}{ }^{2+}$ & 10000.0 & 100.0 & 5000.0 & 100.0 \\
$\mathrm{Cl}^{-}$ & 9100.0 & 100.0 & 5000.0 & 100.0 \\
$\mathrm{H}_{2} \mathrm{PO}_{4}^{-}$ & 1200.0 & 99.9 & 1200.0 & 99.8 \\
$\mathrm{~S}_{2} \mathrm{O}_{3}^{2-}$ & 10000.0 & 100.0 & 500.0 & 100.0 \\
$\mathrm{CH}_{3} \mathrm{COO}^{-}$ & 1000.0 & 100.0 & 500.0 & 100.0 \\
$\mathrm{HCOO}^{-}$ & 10000.0 & 100.0 & 700.0 & 100.0 \\
$\mathrm{C}_{2} \mathrm{O}_{4}^{2-}$ & 500.0 & 99.9 & 250.0 & 99.9 \\
\hline
\end{tabular}

Table 3: Floatability of different concentrations of $\mathrm{Cu}^{2+}$ or $\mathrm{Pb}^{2+}$ ions added to 11 of various water samples using $10 \mathrm{ml}$ of $3 \times 10^{-3} \mathrm{~mol}^{1^{-1}}$ $\mathrm{HOL}$ and $2 \times 10^{-4} \mathrm{~mol}^{-1}$ of $\mathrm{HDPC}$ at $\mathrm{pHs} 6$ for $\mathrm{Cu}^{2+}$ and 7 for $\mathrm{Pb}^{2+}$ ions.

\begin{tabular}{llllll}
\hline $\begin{array}{l}\text { Sample } \\
\text { (Location) }\end{array}$ & $\begin{array}{l}\mathrm{Cu}(\mathrm{II}) \text { or } \mathrm{Pb}(\mathrm{II}) \\
\text { added }(\mathrm{mg})\end{array}$ & $\begin{array}{l}\mathrm{Cu}(\mathrm{II}) \text { found } \\
(\mathrm{mg})\end{array}$ & $\begin{array}{l}\mathrm{F}(\%) \\
\mathrm{Cu}^{2+}\end{array}$ & $\begin{array}{l}\mathrm{Pb}(\mathrm{II}) \\
\text { found } \\
(\mathrm{mg})\end{array}$ & $\begin{array}{l}\mathrm{F}(\%) \\
\mathrm{Pb}^{2+}\end{array}$ \\
\hline Disteled water & 6.5 & 6.494 & 99.9 & 6.480 & 99.7 \\
& 9.5 & 9.490 & 99.9 & 9.480 & 99.8 \\
Tap water & 6.5 & 6.435 & 99.0 & 5.435 & 99.0 \\
(our- lab.) & 9.5 & 9.31 & 98.0 & 9.329 & 98.2 \\
Nile water & 6.5 & 5.859 & 90.0 & 5.859 & 90.0 \\
(Mansoura City) & 9.5 & 8.075 & 85.0 & 8.265 & 87.0 \\
Sea water & 6.5 & 6.494 & 99.9 & 6.494 & 98.9 \\
(Gamasah) & 9.5 & 9.315 & 98.0 & 9.329 & 98.0 \\
Lake water & 6.5 & 6.494 & 99.9 & 6.494 & 97.9 \\
(El-Manzalah) & 9.5 & 9.490 & 99.9 & 9.480 & 98.9 \\
\hline Underground water & 6.5 & 6.494 & 99.8 & 6.422 & 98.8 \\
(Salka) & 9.5 & 9.405 & 99.0 & 9.405 & 99.0 \\
\hline
\end{tabular}

\section{Application}

To investigate the applicability of the recommended procedure, a series of experiments was performed to recover 6.5 and $9.6 \mathrm{mg}$ of $\mathrm{Cu}(\mathrm{II})$ or $\mathrm{Pb}$ (II) spiked to 11 of tap and some natural water samples. The flotation experiments were carried out using clear, filtered through $0.45 \mu \mathrm{m}$ filters, uncontaminated sample solutions after adjusting their $\mathrm{pH}$ values to 6 for $\mathrm{Cu}^{2+}$ and 7 for $\mathrm{Pb}^{2+}$ ions. The results obtained are listed in Table 3. Recovery data indicated that the method could be successfully applied for the separation of $\mathrm{Cu}^{2+}$ and $\mathrm{Pb}^{2+}$ at mean levels of 6.4 and $9.5 \mathrm{mg} \mathrm{l}^{-1}$ from natural water samples containing large amounts of salt matrix under the recommended conditions. Moreover, the recovery was satisfactory and quantitative $(\sim 100 \%)$.
Flotation mechanism

The proposed flotation mechanism for $\mathrm{Cu}^{2+}$ and $\mathrm{Pb}^{2+}$ ions, in the present work, is based upon the following bases:

1. $\mathrm{Cu}^{2+}$ and $\mathrm{Pb}^{2+}$ ions react with HDPC to give $(1: 2)$ complexes as given by Equation (2), which have many sites containing electronegative atoms, such as oxygen and nitrogen, capable of forming hydrogen bonds.

2. Oleic acid begins to dissociated at $\mathrm{pH} \geq 5$ (Ghazy et al., 2004) and the presence of different forms of oleic acid determined by IR analysis at $\mathrm{pH} 9$ (adjusted by $\mathrm{NaOH}$ ) are $13.2 \%$ oleic acid, $68.2 \%$ oleate and $18.2 \%$ sodium oleate , in the form of soap [38]. Therefore, oleic acid can interact with the above complex systems (through hydrogen bonds, either by its un-dissociated or dissociated forms depending on the $\mathrm{pH}$ of the medium) according to the following schemes: 


$$
\begin{aligned}
& (\mathrm{M}-\mathrm{HDPC})-\mathrm{C}=\mathrm{O} \ldots \mathrm{HO}-\mathrm{C}-\mathrm{R} \text { (I) } \\
& \text { where } \mathrm{M} \text { is } \mathrm{Cu}^{2+} \text { or } \mathrm{Pb}^{2+} \text { ion. }
\end{aligned}
$$

3. The combination of oleic acid surfactant with copper-HDPC or Pb-HDPC systems give hydrophobic sublates which float with the aid of air bubbles ( created inside the flotation cell by shaking ) to the solution surface solution (Ghazy et al., 2004).

Conclusion: Diphenylcarbazone (HDPC) was used in this study as a good complexing agent for the heavy meals copper and lead. Flotation technique which has advantages (compared with other separation methods) of being simple, inexpensive, less time consuming and expected to be soon incorporated as a clean technology to treat water and wastewater has been applied in this investigation. The removal of $\mathrm{Cu}$ (II) and $\mathrm{Pb}$ (II) at pHs 6 and 7, respectively attained $\sim 100 \%$ in the presence of HDPC and oleic acid as a cheap surfactant. Moreover, the recommended procedure was successfully applied to some natural water samples and was nearly free from interferences of some selected foreign ions.

\section{REFERENCES}

Agency for Toxic Substances and Disease Registry (ATSDR), 1999. Toxicological Profiles, U.S. Department of Health and Human Services, Public Health Service, Atlanta.

Al-Asheh, S. and Duvnjak, Z., 1997. Binary metal sorption by pine bark, study of equilibria and mechanisms. Sep. Sci. Technol.., 33: 13031329.

Balt, S. and Van Dalen E., 1963. The reactions of diphenylcarbazide and diphenylcarbazone with cations. Anal. Chim. Acta, 29: 466-471.

Blöcher, C., Dorda, J., Mavrov, V., Chmiel, H., Lazaridis, N.K. and Matis K.A., 2003. Hybrid flotation-membrane filtration process for the removal of heavy metal ions from wastewater. Water Res., 37: 4018-4026.

Doyle, F.M., 2003. Ion flotation-its potential for hydrometallurgical operations. Int. J. Miner. Process., 72: 387-399.

Doyle, F.M. and Liu Z., 2003. The effect of triethylenetetraamine (Trien) on the ion flotation of $\mathrm{Cu}^{2+}$ and $\mathrm{Ni}^{2+}$. J. Colloid Interface Sci., 258: 396-403.
Freedman, R., Olson, L. and Hoffer, B.G., 1990. Toxic effects of lead on neuronal development and function. Environ. Health Perspect., 89: 27-34.

Freematle, M.H., 1989. Chemistry in Action. Macmillan Education Ltd., London.

Ghazy, S.E., 1995. Removal of cadmium, lead, mercury, tin, antimony, and arsenic from drinking and seawaters by colloid precipitate flotation. Sep. Sci. Technol., 30, 933-947.

Ghazy, S.E., El-Shazly, R.M., El-Shahawi, M.S., Al-Hazmi, G.A.A. and El-Asmy, A.A., 2006. Spectrophotometric determination of copper(II) in natural waters, vitamins and certified steel scrap samples using acetophenone- $p$ -

chlorophenylthiosemicarbazide. J. Iranian Chem. Soc., 3: 140-150.

Ghazy, S.E. and Kabil, M.A., 1994. Determination of trace copper in natural waters after selective separation by flotation. Bull. Chem. Soc. Jpn., 67: 474-478.

Ghazy, S.E., Mostafa, H.A., El-Farra, S.A. and Fouda A.S., 2004. Flotation-separation of nickel from aqueous media using some hydrazone derivatives as organic collectors and oleic acid as surfactant. Indian J. Chem. Technol., 11, 787-792.

Ghazy, S.E., Samra, S.E. and El-Morsy S.M., 2001. Removal of copper(II) from aqueous solutions using limestone fines as the sorbent and oleic acid as the surfactant. Adsorp. Sci. Technol., 19: $175-185$.

Girek, T., Kozlowski, C.A., Koziol, J.J. and Walkowiak W., 2004. Polymerization of $\beta$ cyclodextrin with succinic anhydride. Synthesis, characterization and ion flotation of transition metals. Carbohydrate Polymers, 59: 211-215.

Gksungure, Y., Uren, S. and Güvenc, U., 2005. Biosorption of cadmium and lead ions by ethanol treated waste baker's yeast biomass. Bioresource Technol., 96: 103-109.

Goldstein, G.W., 1990. Lead poisoning and brain cell function. Environ. Health Perspect., 89: 91-94.

Hasar, H., 2003. Adsorption of nickel(II) from aqueous solution onto activated carbon prepared from almond husk. J. Hazard. Mater., 97: 49-57. 
Ho, Y.S., Ng, J.C.Y. and McKay, G., 2001. Removal of lead(II) from effluents by sorption on peat using second-order kinetics. Sep. Sci. Technol., 36: 241-261.

Kadirvelu, K., Thamaraislvi, K. and Namasivayam C., 2001. Adsorption of nickel(II) from aqueous solution onto activated carbon prepared from coirpith. Sep. Purif. Technol., 24: 497-505.

Khalifa, M.E., Akl, M.A. and Ghazy S.E., 2001. Selective flotation-spectrophotometric determination of trace copper(II) in natural waters, human blood and drug samples using phenanthraquinone monophenylthiosemicarbazone. Chem. Pharm. Bull., 49: 664-668.

Kim, J.S., Akeprathumchia, S. and Wickrasinghe S., 2001. Flocculation to enhance microflotation. J. Member. Sci., 182: 161- 172.

Lazaridis, N.K., Peleka, E.N., Karapantsios, Th.D. and Matis K.A., 2004. Copper removal from effluents by various separation techniques. Hydrometallurgy, 74: 149-156.

Leyden, D.E. and Wegscheider, W., 1981. Preconcentration for trace element determination in aqueous samples. Anal. Chem., 53: 1059A-1065A.

Liu, Z. and Doyle, F.M., 2001a. A thermodynamic approach to ion flotation. I. Kinetics of cupric ion flotation with alkylsulfates. Colloids and Surfaces A, 178, 79-92.

Lui Z. and Doyle F.M., 2001b. Modeling metal ion removal in alkylsulfate ion flotation system. Minerals Metallurgical Processing, 18: 167171.

Matis, K.A. and Mavros P., 1991. Recovery of metals by ion flotation from dilute aqueous solutions. Sep. Purif. Methods, 20: 1-48.

Meunier, N., Laroulandie, J. Blais, J.F., Tyagi, R.D., 2003. Coca shells for heavy metal removal from acidic solutions. Bioresource Technol., 90: 255 - 263.
Rubio, J., Souza, M.L. and Smith R.W., 2002. Overview of flotation as a wastewater treatment technique. Minerals Eng., 15: 139155 .

Sheng, P.X., Ting, Y-P., Chen, J.P. and Hong, L., 2004. Sorption of lead, copper, cadmium, zinc and nickel by marine algal biomass: characterization of biosorptive capacity and investigation of mechanisms. J. Colloid Interface Science, 275: 131-141.

Sitting, M., 1981. Hand Book of Toxic and Hazardous Chemicals. Noyes Publications, Park Ridge, NJ.

Sorensen, E.M.B., 1991. Metal Poisoning in Fish. CRC Press, Boston, MA, USA.

Stalidis, G.A., Matis, K.A. and Lazaridis, N.K., 1989. Selictive separation of $\mathrm{Cu}, \mathrm{Zn}$ and $\mathrm{As}$ from solutions by flotation techniques. Sep. Sci. Technol., 24: 97-109.

Steven, W.I.., 1966. Extraction and stability of copper complexes of 1,5-diphenylcarbazone. Anal. Chim. Acta, 36: 537-540.

Stoica, L., Constantin, C., Meghea, A. and Micu, O., 2001. Alkylhydroxamic acids with $\mathrm{Cu}(\mathrm{II})$ and $\mathrm{Co}$ (II) interaction in metallic ion flotation. Environ. Protect. Ecol., 2, 1015-1019.

Stoica, L., Dinculescu, M. and Plapcianu C.G., 1998. Mn(II) recovery from aqueous systems by flotation. Water Res., 32: 3021-3030.

Trinder, N., 1966. The use of diphenylcarbazone for the determination of microgram amounts of lead. Analyst, 91: 587-590.

Yan, G. and Viraraghavan, T., 2003. Heavy-metal removal from aqueous solution by fungus Mucor rouxii. Water Res., 37: 4446 - 4496.

Zouboulis, A.I., Lazaridis, N.K., Zamboulis, D., 1994. Powdered activated carbon separation from water by foam floation. Sep. Sci. Technol., 29: 385-400. 